\title{
Analisa Strategi Pemberdayaan Komponen Maritim dalam Mendukung Operasi Keamanan Laut Nasional
}

\author{
Ahmadi ${ }^{1}$, Didit Herdiawan ${ }^{2}$, Okol Sri Suharyo ${ }^{3}$ \\ 1,2,3 Sekolah Tinggi Teknologi Angkatan Laut (STTAL) Surabaya \\ ${ }^{1}$ dr_ahmadi@sttal.ac.id ${ }^{3}$ okolsrisuharyo@sttal.ac.id
}

DOI: https://doi.org/10.21107/rekayasa.v13i1.5873

\begin{abstract}
ABSTRAK
Strategi pemberdayaan komponen maritim merupakan salah satu tugas pokok TNI AL, sebagai komponen perkuatan pertahanan dan keamanan di Laut. Salah satu case study yang bisa diangkat dalam pemberdayaan komponen maritim adalah pemberdayaan Selat Lombok. Selat Lombok merupakan salah satu pintu gerbang masuk jalur pelayaran Internasional yang mendapatkan prioritas keamanan maritim (maritime security) dan keselamatan maritim (maritime safety). Pemerintah Indonesia memberikan tugas untuk menjaga keamanan dan keselamatan maritim di Selat Lombok kepada komponen maritim antara lain TNI Angkatan Laut, Bakamla, Polairud, Dishubla, KSOP, Pemda serta institusi lain sebagainya. Untuk melaksanakan tugas tersebut, Pimpinan Angkatan Laut menginginkan agar Lanal di Selat Lombok dapat melaksanakan tugas dan fungsinya dengan optimal ditengah keterbatasan kemampuan yang dimiliki. Maka diperlukan strategi tentang pemberdayaan komponen maritim agar mendukung operasi keamanan laut di Selat Lombok. Penulisan paper ini bertujuan mengidentifikasi dan menentukan strategi pemberdayaan komponen maritim dalam mendukung operasi keamanan laut di Selat Lombok dengan metode pendekatan AHP-SWOT. Hasil analisa mengidentifikasi 26 kriteria dari 4 aspek yaitu Politik, Keamanan, Sosial-Ekonomi dan Teknis. Faktor pemenuhan informasi intelijen, peningkatan kekuatan kapal patroli, peningkatan fasilitas pelabuhan dan fasilitas dukungan administrasi menjadi faktor penentu keberhasilan operasi keamanan laut di Selat Lombok. Dengan segala keterbatasan Pangkalan Angkatan Laut maka strategi W-T (Defensif) menjadi strategi terbaik pada proses sinergitas komponen maritim. Meningkatkan kemampuan informasi intelijen (W-T4) menjadi prioritas rumusan strategi dengan bobot $21 \%$ dan skornya adalah 1,557. Secara keseluruhan sinergitas komponen maritim dalam mendukung operasi keamanan laut di Selat Lombok diharapkan dapat meningkatkan stabilitas keamanan maritim di wilayah teritorial Selat Lombok.

Kata Kunci : Strategi Pemberdayaan, Komponen Maritim, SWOT.
\end{abstract}

\section{LATAR BELAKANG}

Indonesia adalah negara maritim terbesar di dunia, yang memiliki 17.504 pulau yang wilayah teritorialnya didominasi lautan (Pushidrosal, 2018). Sebagai negara maritim, Indonesia memiliki 4 (empat) titik yang menjadi chokepoints internasional yaitu Selat Malaka, Selat Sunda, Selat Lombok serta Selat Ombai-Wetar (Rodrigue, 2004). Selat Lombok merupakan salah satu pintu gerbang masuk jalur pelayaran (Chokepoint - ALKI II) dan juga merupakan jalur utama perdagangan Asia-Australia. Jalur pelayaran di Selat Lombok menjadi prioritas pembangunan jalur transportasi laut dikarenakan secara geografis jalur di Selat Lombok yang memiliki panjang 60 kilometer dengan lebar 18-30 kilometer dan kedalaman mencapai lebih dari 1000 meter tidak banyak terhalang pulau dan layak untuk dilewati kapal-kapal besar (Akimoto, 2001).

Untuk menjaga jalur pelayaran perdagangan di Selat Lombok maka pemerintah perlu memenuhi

\section{Article History:}

Received: August, 27 th 2019; Accepted: January, $12^{\text {th }} 2020$ ISSN: 2502-5325 (Online) Terakreditasi Peringkat 3 oleh Kementerian Riset, Teknologi dan Pendidikan Tinggi (ARJUNA), berdasarkan Keputusan Direktur Jenderal Penguatan Riset dan Pengembangan No: 23/E/KPT/2019 tanggal 8 Agustus 2019 persyaratan keamanan maritim (maritime security) dan persyaratan keselamatan maritim (maritime safety) (Kadarisman, 2017). Tugas menjaga keamanan dan keselamatan maritim diberikan kepada beberapa institusi atau komponen maritim antara lain TNI Angkatan Laut, Bakamla, Polairud, Dishubla, KKP, Pemda serta institusi lain sebagainya. Meskipun ada berbagai instansi yang terlibat dalam menjaga keamanan maritim di Selat Lombok

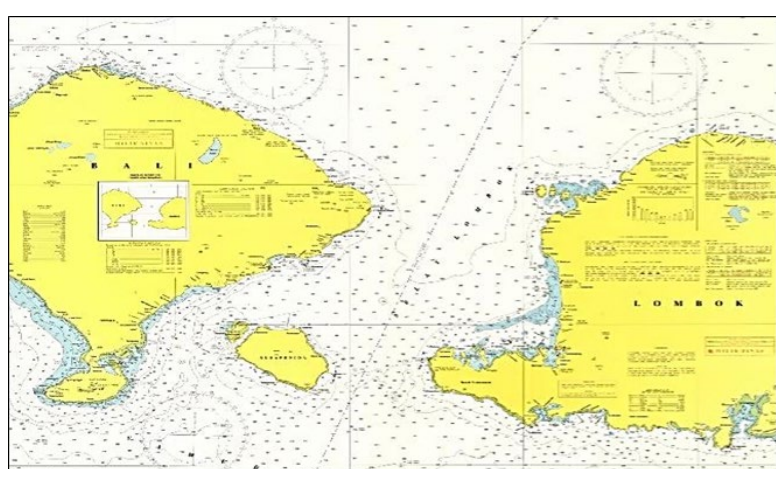

Gambar 1. Peta Selat Lombok Sumber : (Pushidrosal, 2018)

Cite this as:

Ahmadi, A., Herdiawan, D., \& Suharyo, O.S. (2020). Analisa Strategi Pemberdayaan Komponen Maritim dalam Mendukung Operasi Keamanan Laut Nasional. Rekayasa, 13(1), 38-44. doi: https://doi.org/10.21107/rekayasa.v13i1.5873

(c) 2020 Author(s) 
namun gejala atau indikasi pelanggaran keamanan laut di Selat Lombok terus meningkat. Hal tersebut karena belum adanya formulasi strategi bersama dalam pelaksanaan tugas keamanan maritim. Berdasarkan data Badan Pusat Statistik (BPS) tahun 2016 berbagai ancaman maritim di Selat Lombok masih sering terjadi dengan kecenderungan terus meningkat.

Permasalahan utama yang dapat diangkat dalam paper ini adalah Bagaimana Strategi Pemberdayaan Komponen Maritim Dalam Mendukung Operasi Keamanan Laut Nasional di Selat Lombok. Untuk mengurangi berbagai pelanggaran yang terjadi di Selat Lombok maka TNI Angkatan Laut sebagai motor dari komponen keamanan maritim menyelenggarakan Operasi Keamanan Laut (Opskamla) dengan dukungan dari seluruh komponen maritim lainnya dalam bentuk pemberdayaan pelaksanaan tugas opskamla yang disebut juga sinergitas. Sinergitas yang dimaksud adalah melaksanakan kerjasama unsur di teritorial tugas untuk menghasilkan tujuan yang lebih baik daripada sendiri. Salah satu bentuk sinergitas adalah dengan bekerjasama dalam meningkatkan kesiapan unsur yang beroperasi dan penambahan jumlah sarana dan prasarana di Pangkalan Angkatan Laut (Keputusan Kasal Nomor 1424, 2016).

Sasaran dari penulisan paper ini adalah perumusan strategi pemberdayaaan komponen maritim di wilayah Selat Lombok, yang meliputi strategi aspek politik, keamanan, sosial-ekonomi dan teknis. Hal ini dilakukan karena pemberdayaan yang selama ini telah dilakukan belum memiliki kesamaan tujuan dalam mengoptimalkan kekuatan dari masing-masing instansi serta saling mendukung pelaksanaan tugas operasi keamanan laut di Selat Lombok. Karena belum ada prioritas pemberdayaan antar komponen maritim maka pada gelar operasi keamanan laut di Selat Lombok sampai saat ini belum dapat menurunkan jumlah pelanggaran di laut teritorial.

Adapun tujuan dari penulisan paper ini adalah bagaimana mengidentifikasi faktor-faktor yang berpengaruh dalam mendukung opskamla dan bagaimana implementasi strategi pemberdayaan komponen maritim $\mathrm{TNI} A \mathrm{~L}$, sehingga dapat ditentukan strategi pemberdayaan terbaik dalam mendukung operasi keamanan laut oleh seluruh komponen maritim nasional.

\section{METODE PENELITIAN}

Adapun Metode yang digunakan adalah dengan pendekatan metode SWOT, dengan beberapa tahapan yang meliputi :

\section{Identifikasi Faktor Pemberdayaan.}

Proses analisis mengidentifikasi dilaksanakan dengan menentukan faktor yang berpengaruh pada opskamla dari aspek politik, keamanan, sosial-ekonomi dan teknis. Kemudian dengan pendekatan SWOT faktor pengaruh tersebut dinilai untuk mendapatkan nilai prioritas faktor yang berpengaruh dalam mendukung opskamla di Selat Lombok.

\section{Penentuan Strategi Pemberdayaan}

Proses penentuan strategi pemberdayaan dilakukan dengan mengidentifikasi faktor internal dan eksternal di teritorial Lanal Denpasar dan Lanal Mataram. Selanjutnya dianalisis kebutuhan sinergi komponen maritim berdasarkan kebutuhan sinergi dalam mendukung opskamla dan menentukan strategi-strategi pemberdayaan berdasarkan besaran bobot berbagai kriteria dengan pendekatan SWOT tampak pada gambar 2.

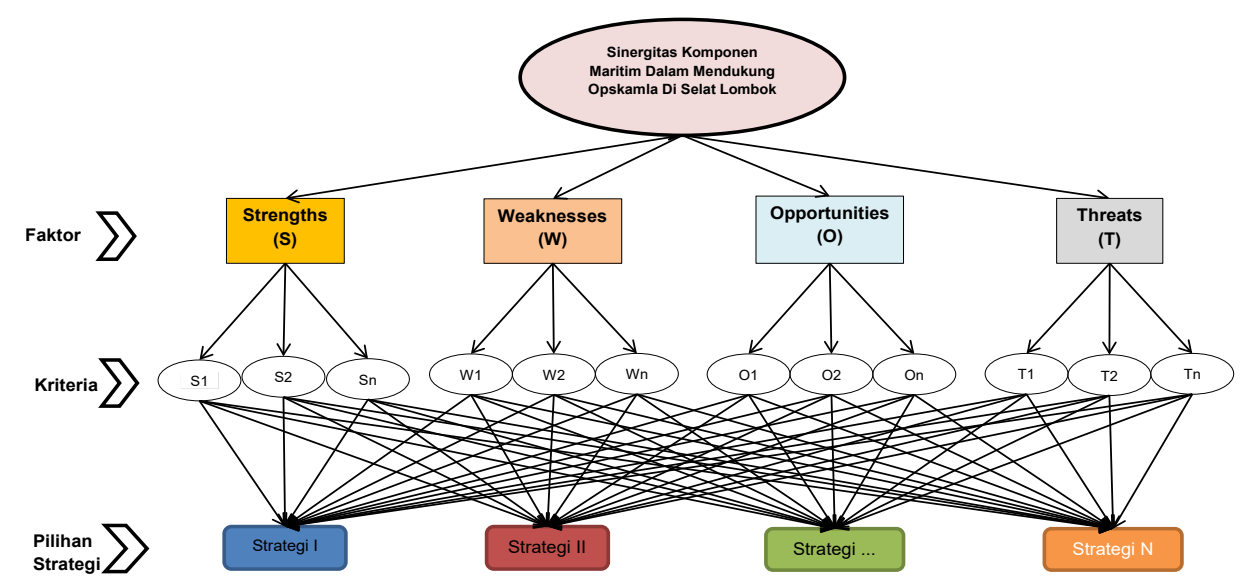

Gambar 2. Diagram Strategi Pemberdayaan dengan Analisa SWOT 


\section{Analisa SWOT.}

Dalam menentukan strategi pemberdayaan maka dilakukan dengan melakukan analisis terhadap kekuatan (Strengths), kelemahan (Weaknesses), peluang (Opportunities), dan ancaman (Threats) atau SWOT di lingkungan Lanal Denpasar dan Lanal Mataram.

Analisis SWOT adalah metode yang digunakan untuk menganalisis suatu lingkungan operasional. Analisis SWOT diterapkan dengan cara menganalisis dan memilah berbagai hal yang mempengaruhi keempat faktornya. Analisis ini diawali dengan melakukan identifikasi faktor internal dan identifikasi faktor eksternal, kemudian menerapkannya dalam gambar matrik SWOT (Mobaraki, 2014). Analisis SWOT didasarkan pada logika memaksimalkan kekuatan dan peluang, namun secara bersamaan dapat meminimalkan kelemahan dan Ancaman (Ayub et al., 2013). Analisis SWOT diperoleh dengan mengidentifikasi kondisi, potensi dan permasalahan menggunakan strategi S-O, W-O, S-T, dan W-T (Gretzky, 2010).

\section{HASIL DAN PEMBAHASAN}

\section{Identifikasi Faktor Strategi}

Langkah awal dalam program ini adalah mengidentifikasi Faktor Internal dan Eksternal dengan pendekatan metode SWOT. Identifikasi faktor Internal dilakukan untuk mengetahui faktor-faktor yang menjadi kekuatan atau Strengths (S) dan kelemahan atau Weaknesses (W), sedangkan identifikasi faktor Eksternal dilakukan untuk mengetahui faktor yang menjadi peluang atau Opportunities $(\mathrm{O})$ dan ancaman atau Threats $(\mathrm{T})$.

Tabel 1. Identifikasi Faktor Internal Pangkalan TNI AL

\begin{tabular}{clcc}
\hline No & $\begin{array}{c}\text { Kriteria Faktor Internal } \\
\text { (Streght - Weakness) }\end{array}$ & $\begin{array}{c}\text { Skor Faktor } \\
\text { Pengaruh }\end{array}$ & Bobot \\
\hline 1 & Posisi Strategis & 0,075 & 0,144 \\
2 & Kekuatan Patkamla & 0,056 & 0,107 \\
3 & Covered Area Opskamla & 0,051 & 0,096 \\
4 & Kemampuan Patkamla & 0,061 & 0,116 \\
5 & Kemampuan Intelijen & 0,077 & 0,148 \\
6 & Manajemen Anggaran & 0,029 & 0,055 \\
7 & Kemampuan SDM & 0,046 & 0,087 \\
8 & Dukungan Logistik & 0,025 & 0,048 \\
9 & Kemampuan Faslabuh & 0,030 & 0,058 \\
10 & Kemampuan Fasharkan & 0,012 & 0,023 \\
11 & Kemampuan Fasbekal & 0,016 & 0,030 \\
12 & Kemampuan Fasmako & 0,027 & 0,052 \\
13 & Kemampuan Fasum & 0,018 & 0,035 \\
& Total Bobot & & $\mathbf{1 , 0 0 0}$ \\
\hline
\end{tabular}

Tabel 2. Identifikasi Faktor Eksternal Pangkalan TNI $\mathrm{AL}$

\begin{tabular}{clcc}
\hline No & $\begin{array}{c}\text { Kriteria Faktor Eksternal } \\
\text { (Opportunity - Threats }\end{array}$ & $\begin{array}{c}\text { Skor Faktor } \\
\text { Pengaruh }\end{array}$ & Bobot \\
\hline 1 & Kebijakan Opskamla & 0,039 & 0,081 \\
2 & Potensi Maritim & 0,077 & 0,161 \\
3 & Dukungan Komponen Maritim & 0,036 & 0,076 \\
4 & Kebijakan Pembangunan & 0,038 & 0,079 \\
& Maritim & & \\
5 & Prioritas Pembangunan Daerah & 0,040 & 0,085 \\
6 & Dinamika Lingkungan Strategis & 0,038 & 0,079 \\
7 & Ancaman Kamla & 0,057 & 0,120 \\
8 & Volume Pelayaran & 0,022 & 0,046 \\
9 & Industri Maritim & 0,017 & 0,037 \\
10 & Pariwisata Maritim & 0,034 & 0,072 \\
11 & Sistem Informasi & 0,031 & 0,066 \\
12 & Teknologi Navigasi & 0,021 & 0,044 \\
13 & Sistem Keselamatan & 0,025 & 0,053 \\
& & Total Bobot & $\mathbf{1 , 0 0 0}$ \\
\hline
\end{tabular}

Selanjutnya semua faktor dinilai dengan diberi Skor sebagai faktor yang berpengaruh dan diberi bobot tingkat kepentingan sesuai peran masing-masing. Berikut ini adalah Tabel 1 dan Tabel 2 tentang Identifikasi Faktor Internal dan Eksternal Pangkalan TNI AL (Lanal).

\section{Analisa Strategi SWOT - Lanal Denpasar}

Dalam penyusunan rumusan strategi di Lanal Denpasar dilakukan dengan membuat analisis besaran skor pengaruh pada seluruh matriks SWOT. Adapun analisis ranking matriks SWOT Kekuatan (Strengths) dan faktor Kelemahan (Weaknesses) serta faktor Peluang (Opportunities) dan faktor Ancaman (Threats) untuk Lanal Denpasar seperti dalam Tabel 3.

\section{Analisa Strategi SWOT- Lanal Mataram}

Penilaian (assessment) juga dilakukan terhadap kondisi saat ini di teritorial Lanal Mataram untuk pengklasifikasian faktor Kekuatan (Strengths) dan faktor Kelemahan (Weaknesses) serta faktor Peluang (Opportunities) dan faktor Ancaman (Threats), seperti dalam Tabel 4.

\section{Perumusan Solusi Strategi}

Solusi strategi yang dihasilkan merupakan analisis dari perpaduan pada matriks SWOT Lanal Denpasar dan Lanal Mataram, seperti ditunjukkan pada Tabel 5. Analisis Koordinat Garis SWOT berikut ini.

Dari Tabel 5. dapat diketahui bahwa perpotongan garis kuadran strategi pemberdayaan di wilayah teritorial Lanal Denpasar maupun Lanal Mataram berada pada Kuadran IV (W-T, Weakness-Threats). Posisi perpotongan di Kuadran IV diidentifikasikan dimana kondisi yang ada saat ini mendukung untuk memakai Strategi W-T / Defensif (Retrenchment). Strategi Defensif ini berfungsi untuk 
Tabel 3. Analisa SWOT Lanal Denpasar beserta Bobotnya

\begin{tabular}{|c|c|c|c|c|}
\hline $\begin{array}{l}\text { Skor } \\
\text { SWOT }\end{array}$ & Kode & $\begin{array}{l}\text { Faktor } \\
\text { Pengaruh }\end{array}$ & $\begin{array}{l}\text { Score } \\
\text { Bobot }\end{array}$ & $\begin{array}{l}\text { Bobot } \\
\text { SWOT } \\
\text { (Skor Bo- } \\
\text { bot/ } / \sum \text { skor } \\
\text { Bobot) }\end{array}$ \\
\hline \multirow{4}{*}{$\begin{array}{c}\text { Kekuatan } \\
\text { Strengths } \\
\text { (S) } \\
1,051\end{array}$} & S-1 & Posisi Strategis & 1,013 & 0,087 \\
\hline & S-2 & $\begin{array}{l}\text { Dukungan } \\
\text { Logistik }\end{array}$ & 0,277 & 0,024 \\
\hline & S-3 & $\begin{array}{l}\text { Kemampuan } \\
\text { SDM }\end{array}$ & 0,477 & 0,041 \\
\hline & S-4 & $\begin{array}{l}\text { Kemampuan } \\
\text { Fasmako }\end{array}$ & 0,284 & 0,024 \\
\hline \multirow{9}{*}{$\begin{array}{c}\text { Kelema- } \\
\text { han } \\
\text { Weak- } \\
\text { nesses } \\
(W) \\
2,246\end{array}$} & W-1 & $\begin{array}{l}\text { Kemampuan } \\
\text { Intelijen }\end{array}$ & 0,794 & 0,068 \\
\hline & $W-2$ & $\begin{array}{l}\text { Manajemen } \\
\text { Anggaran }\end{array}$ & 0,278 & 0,024 \\
\hline & $W-3$ & $\begin{array}{l}\text { Kemampuan } \\
\text { Fasum }\end{array}$ & 0,172 & 0,015 \\
\hline & W-4 & $\begin{array}{l}\text { Kemampuan } \\
\text { Fasbekal }\end{array}$ & 0,143 & 0,012 \\
\hline & W-5 & $\begin{array}{l}\text { Kemampuan } \\
\text { Faslabuh }\end{array}$ & 0,277 & 0,024 \\
\hline & W-6 & $\begin{array}{l}\text { Kekuatan Pat- } \\
\text { kamla }\end{array}$ & 0,509 & 0,044 \\
\hline & W-7 & $\begin{array}{l}\text { Kemampuan } \\
\text { Patkamla }\end{array}$ & 0,535 & 0,046 \\
\hline & W-8 & Covered Area & 0,448 & 0,038 \\
\hline & W-9 & $\begin{array}{l}\text { Kemampuan } \\
\text { Fasharkan }\end{array}$ & 0,090 & 0,008 \\
\hline \multicolumn{3}{|c|}{$\begin{array}{c}\text { Peluang } \\
\text { Opportunities (O) } \\
1,610 \\
\text { O-1 } \\
\text { Pariwisata Maritim }\end{array}$} & 0,543 & 0,047 \\
\hline \multirow{13}{*}{$\begin{array}{c}\text { An- } \\
\text { caman } \\
\text { Threats } \\
(T) \\
1,761\end{array}$} & $0-2$ & Potensi Maritim & 1,122 & 0,096 \\
\hline & $0-3$ & $\begin{array}{l}\text { Kebijakan } \\
\text { Maritim }\end{array}$ & 0,529 & 0,045 \\
\hline & $0-4$ & $\begin{array}{l}\text { Dukungan } \\
\text { Institusi }\end{array}$ & 0,493 & 0,042 \\
\hline & $0-5$ & $\begin{array}{l}\text { Sistem Infor- } \\
\text { masi }\end{array}$ & 0,423 & 0,036 \\
\hline & $\mathrm{T}-1$ & $\begin{array}{l}\text { Kebijakan } \\
\text { Kamla }\end{array}$ & 0,517 & 0,044 \\
\hline & $\mathrm{T}-2$ & $\begin{array}{l}\text { Pembangunan } \\
\text { Daerah }\end{array}$ & 0,531 & 0,045 \\
\hline & $\mathrm{T}-3$ & $\begin{array}{l}\text { Sistem Kesela- } \\
\text { matan }\end{array}$ & 0,326 & 0,028 \\
\hline & $\mathrm{T}-4$ & $\begin{array}{l}\text { Volume Pela- } \\
\text { yaran }\end{array}$ & 0,281 & 0,024 \\
\hline & $\mathrm{T}-5$ & $\begin{array}{l}\text { Teknologi Nav- } \\
\text { igasi }\end{array}$ & 0,268 & 0,023 \\
\hline & $\mathrm{T}-6$ & $\begin{array}{l}\text { Ancaman Kea- } \\
\text { manan Laut }\end{array}$ & 0,707 & 0,061 \\
\hline & $\mathrm{T}-7$ & $\begin{array}{l}\text { Dinamika } \\
\text { Lingstra }\end{array}$ & 0,442 & 0,038 \\
\hline & $\mathrm{T}-8$ & Industri Maritim & 0,191 & 0,016 \\
\hline & & Total & 11,647 & 1,000 \\
\hline
\end{tabular}

Tabel 4. Analisa SWOT Lanal Mataram

\begin{tabular}{|c|c|c|c|c|}
\hline $\begin{array}{l}\text { Skor } \\
\text { SWOT }\end{array}$ & Kode & $\begin{array}{c}\text { Faktor } \\
\text { Pengaruh }\end{array}$ & $\begin{array}{l}\text { Score } \\
\text { Bobot }\end{array}$ & $\begin{array}{c}\text { Bobot } \\
\text { SWOT } \\
\text { (Skor } \\
\text { Bobo- } \\
\text { t/ } / \text { Skor } \\
\text { Bobot) }\end{array}$ \\
\hline \multirow{6}{*}{$\begin{array}{c}\text { Kekuatan } \\
\text { Strengths } \\
\text { (S) } \\
0,574\end{array}$} & S-1B & Posisi Strategis & 0,524 & 0,100 \\
\hline & $S-2 B$ & $\begin{array}{l}\text { Dukungan } \\
\text { Logistik }\end{array}$ & 0,140 & 0,027 \\
\hline & $\mathrm{S}-3 \mathrm{~B}$ & $\begin{array}{l}\text { Kemampuan } \\
\text { Faslabuh }\end{array}$ & 0,161 & 0,031 \\
\hline & $\mathrm{W}-1 \mathrm{~B}$ & $\begin{array}{l}\text { Kemampuan } \\
\text { Fasbekal }\end{array}$ & 0,078 & 0,015 \\
\hline & $W-2 B$ & $\begin{array}{l}\text { Kemampuan } \\
\text { Intelijen }\end{array}$ & 0,386 & 0,073 \\
\hline & $W-3 B$ & $\begin{array}{l}\text { Kemampuan } \\
\text { SDM }\end{array}$ & 0,223 & 0,042 \\
\hline \multirow{8}{*}{$\begin{array}{c}\text { Kelemahan } \\
\text { Weakness- } \\
\text { es }(W) \\
2,481\end{array}$} & $W-4 B$ & $\begin{array}{l}\text { Manajemen } \\
\text { Anggaran }\end{array}$ & 0,140 & 0,027 \\
\hline & $W-5 B$ & $\begin{array}{l}\text { Kekuatan Pat- } \\
\text { kamla }\end{array}$ & 0,257 & 0,049 \\
\hline & $W-6 B$ & Covered Area & 0,231 & 0,044 \\
\hline & $W-7 B$ & $\begin{array}{l}\text { Kemampuan } \\
\text { Fasmako }\end{array}$ & 0,124 & 0,024 \\
\hline & $W-8 B$ & $\begin{array}{l}\text { Kemampuan } \\
\text { Patkamla }\end{array}$ & 0,247 & 0,051 \\
\hline & $W-9 B$ & $\begin{array}{l}\text { Kemampuan } \\
\text { Fasharkan }\end{array}$ & 0,050 & 0,009 \\
\hline & W-10B & $\begin{array}{l}\text { Kemampuan } \\
\text { Fasum }\end{array}$ & 0,068 & 0,013 \\
\hline & $\mathrm{O}-1 \mathrm{~B}$ & Potensi Maritim & 0,941 & 0,094 \\
\hline \multirow{5}{*}{$\begin{array}{c}\text { Peluang } \\
\text { Opportuni- } \\
\text { ties (O) } \\
0,956\end{array}$} & $\mathrm{O}-2 \mathrm{~B}$ & $\begin{array}{l}\text { Dukungan } \\
\text { Institusi }\end{array}$ & 0,423 & 0,042 \\
\hline & $\mathrm{O}-3 \mathrm{~B}$ & $\begin{array}{l}\text { Volume Pela- } \\
\text { yaran }\end{array}$ & 0,236 & 0,024 \\
\hline & $0-4 \mathrm{~B}$ & $\begin{array}{l}\text { Pariwisata } \\
\text { Maritim }\end{array}$ & 0,356 & 0,035 \\
\hline & $\mathrm{T}-1 \mathrm{~A}$ & $\begin{array}{l}\text { Kebijakan } \\
\text { Maritim }\end{array}$ & 0,394 & 0,039 \\
\hline & $\mathrm{T}-2 \mathrm{~A}$ & $\begin{array}{l}\text { Pembangunan } \\
\text { Daerah }\end{array}$ & 0,415 & 0,041 \\
\hline \multirow{8}{*}{$\begin{array}{c}\text { Ancaman } \\
\text { Threats } \\
(T) \\
2,027\end{array}$} & $\mathrm{~T}-3 \mathrm{~A}$ & $\begin{array}{l}\text { Dinamika } \\
\text { Lingstra }\end{array}$ & 0,385 & 0,038 \\
\hline & $\mathrm{T}-4 \mathrm{~A}$ & Kebijakan Kamla & 0,388 & 0,039 \\
\hline & $\mathrm{T}-5 \mathrm{~A}$ & Ancaman Kamla & 0,558 & 0,056 \\
\hline & $\mathrm{T}-6 \mathrm{~A}$ & $\begin{array}{l}\text { Sistem Infor- } \\
\text { masi }\end{array}$ & 0,301 & 0,030 \\
\hline & $\mathrm{T}-7 \mathrm{~A}$ & $\begin{array}{l}\text { Teknologi Nav- } \\
\text { igasi }\end{array}$ & 0,199 & 0,020 \\
\hline & $\mathrm{T}-8 \mathrm{~A}$ & Industri Maritim & 0,164 & 0,016 \\
\hline & $\mathrm{T}-9 \mathrm{~A}$ & $\begin{array}{l}\text { Sistem Kesela- } \\
\text { matan }\end{array}$ & 0,224 & 0,022 \\
\hline & & Jumlah & 10,038 & 1,000 \\
\hline
\end{tabular}

Tabel 5. Analisis Koordinat Perpotongan Garis Matriks SWOT

\begin{tabular}{|c|c|c|c|c|c|c|}
\hline \multirow{2}{*}{ Lanal } & \multicolumn{4}{|c|}{ Skor } & \multirow{2}{*}{$\begin{array}{c}\text { Sumbu } \\
X \\
(S-W)\end{array}$} & \multirow{2}{*}{$\begin{array}{c}\underset{Y}{S u m b u} \\
(\mathrm{O}-\mathrm{T})\end{array}$} \\
\hline & $\mathbf{S}$ & $\mathbf{w}$ & 0 & $\mathbf{T}$ & & \\
\hline Denpasar & 1,051 & 2,246 & 1,610 & 1,762 & $-1,195$ & $-0,152$ \\
\hline Mataram & 0,574 & 2,481 & 0,956 & 2,027 & $-1,907$ & $-1,072$ \\
\hline
\end{tabular}




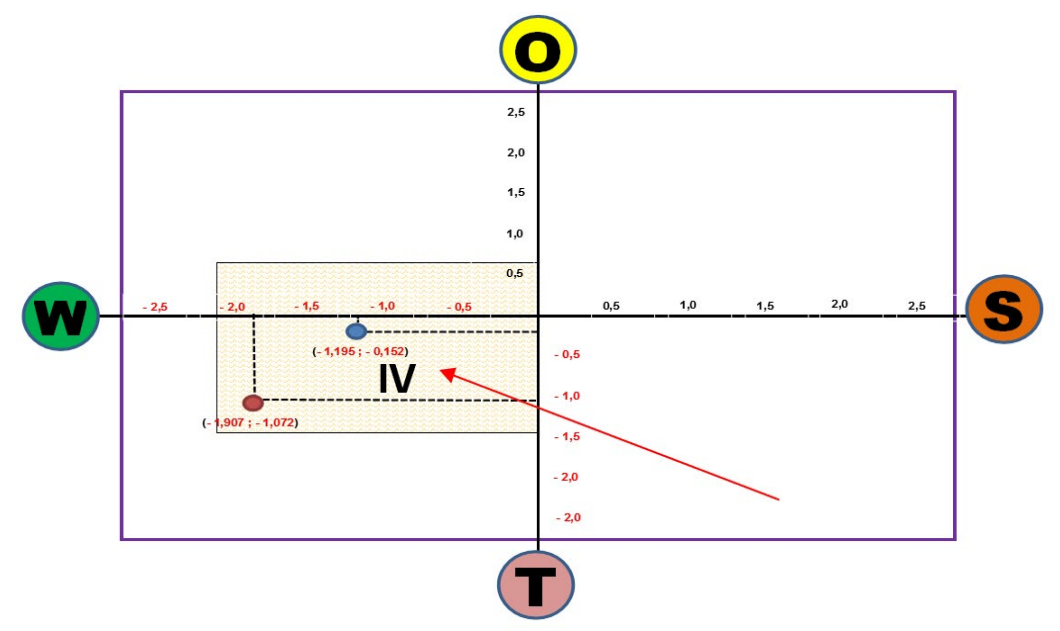

Gambar 3. Perumusan Strategi SWOT berada pada Kuadran W-T (Weakness-Threats)

Tabel 6. Solusi Potensial Rumusan Strategi Pemberdayaan Komponen Maritim

\begin{tabular}{|c|c|}
\hline Strategi & Uraian \\
\hline W-T1 & $\begin{array}{l}\text { Lanal bekerjasama dengan Polairud meman- } \\
\text { faatkan informasi intelijen untuk mengurangi } \\
\text { ancaman yang dapat mengganggu jalur } \\
\text { pelayaran. }\end{array}$ \\
\hline W-T2 & $\begin{array}{l}\text { Lanal bekerjasama dengan Pemda dalam } \\
\text { memprioritaskan pembangunan daerahnya } \\
\text { untuk peningkatan kemampuan Faslabuh } \\
\text { yang dibutuhkan opskamla }\end{array}$ \\
\hline W-T3 & $\begin{array}{l}\text { Lanal bekerjasama dengan Pemda ikut serta } \\
\text { memprioritaskan pembangunan daerahnya } \\
\text { dalam menambah kekuatan Patkamla Lanal }\end{array}$ \\
\hline W-T4 & $\begin{array}{l}\text { Lanal bekerjasama dengan institusi KSOP da- } \\
\text { lam mengelola sumber intelijen dari sistem in- } \\
\text { formasi keamanan dan keselamatan pelayaran } \\
\text { yang dimiliki institusi. }\end{array}$ \\
\hline W-T5 & $\begin{array}{l}\text { Lanal bekerjasama dengan Pemda ikut serta } \\
\text { memprioritaskan usaha meningkatkan indus- } \\
\text { tri maritim dalam rangka pembinaan potensi } \\
\text { masyarakat pesisir }\end{array}$ \\
\hline W-T6 & $\begin{array}{l}\text { Lanal bekerjasama dengan institusi Polairud } \\
\text { dan KSOP dalam rangka meningkatkan ke- } \\
\text { mampuan SDM terhadap sistem keselamatan } \\
\text { pelayaran }\end{array}$ \\
\hline
\end{tabular}

mempertahankan kondisi organisasi walaupun dengan segala keterbatasan. Adapun gambaran perumusan strategi pemberdayaan seperti pada Gambar 3.

\section{Strategi Pemberdayaan Komponen Maritim}

Dari keenam analisis prioritas rumusan strategi W-T (Weakness-Threat) di kedua teritorial Pangkalan TNI AL (Lanal Denpasar dan Lanal Mataram) di atas akan dirumuskan Strategi Pemberdayaan yang menjadi Solusi Potensial yaitu pada tabel 6 .

Selanjutnya dengan Metode LOW COST HIGH IM$P A C T$, seluruh solusi potensial strategi tersebut di atas apabila dikelompokkan dalam beberapa alternatif solusi strategi maka diperoleh Gambar 4.

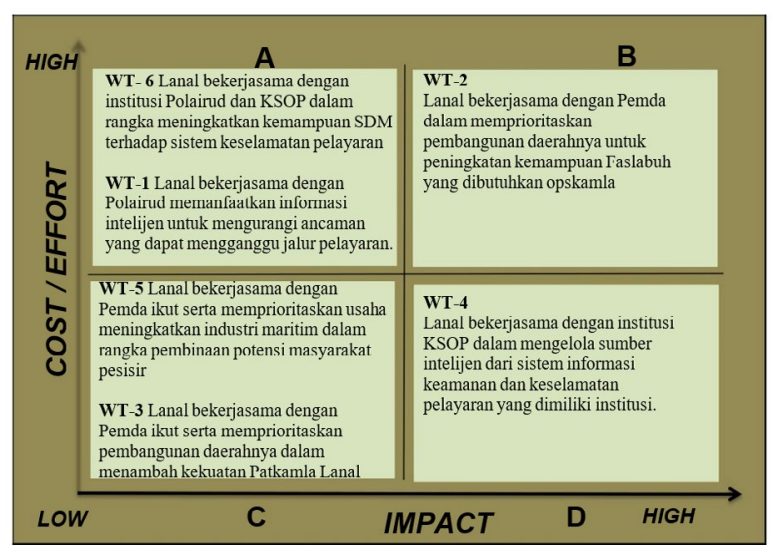

Gambar 4. Analisa Strategi Potensial dengan

\section{Penetapan Solusi Potensial}

Hasil dari pembobotan terhadap alternatif strategi W-T1 sd. WT6 dengan menggunakan pendekatan SWOT dan metode LOW COST HIGH IMPACT, didapatkan bahwa strategi W-T4 menjadi prioritas strategi atau SOLUSI POTENSIAL terbaik dari strategi sinergitas Pangkalan Angkatan Laut. dengan bobot $20,7 \%$.

\section{Analisa Solusi Potensial}

Langkah selanjutnya adalah melakukan analisa solusi potensial untuk mendapatkan usulan solusi berdasarkan kriteria Output, Biaya, Waktu, Pertimbangan Khusus dan Resiko, yang dapat dijelaskan dalam Tabel 7.

Strategi W-T4 lebih realistis untuk dilaksanakan pada situasi keterbatasan stakeholder dan kondisi komponen maritim saat ini. Instansi KSOP dan Lanal selaku pengelola sumber informasi pelayaran saat ini, dalam kondisi sangat siap mendukung operasi keamanan laut dalam bentuk memberikan informasi dan data pelayaran yang bersumber dari radar Vessel Traffic Service (VTS). Yang diperlukan dalam kerjasama tersebut adalah MoU yang rinci tentang pengawakan dan penggunaan sistem 


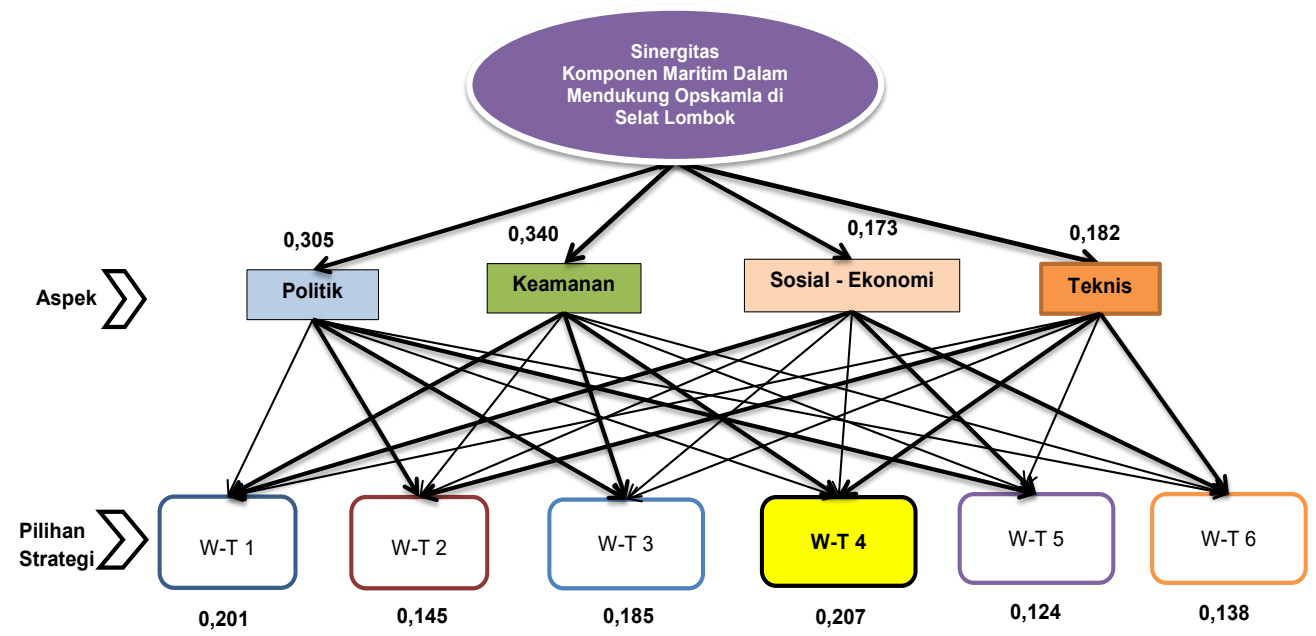

Tabel 7. Analisa Solusi Potensial

Gambar 5. Bobot Alternatif Strategi Pemberdayaan

\begin{tabular}{|c|c|c|}
\hline No & KRITERIA & USULAN SOLUSI \\
\hline 1 & Output & $\begin{array}{l}\text { Lanal bekerjasama dengan institu- } \\
\text { si KSOP dalam mengelola sumber } \\
\text { intelijen dari sistem informasi } \\
\text { keamanan dan keselamatan pela- } \\
\text { yaran yang dimiliki institusi. }\end{array}$ \\
\hline 2 & Biaya & $\begin{array}{l}\text { Biaya dapat ditekan seminimal } \\
\text { mungkin dan dapat diajukan ke } \\
\text { Mabesal dan Institusi KSOP untuk } \\
\text { dikerjasamakan }\end{array}$ \\
\hline 3 & Waktu & $\begin{array}{l}\text { Mulai tahap perjanjian hingga } \\
\text { pendalaman dan kerjasama mem- } \\
\text { butuhkan waktu maksimal } 2 \text { bulan }\end{array}$ \\
\hline 4 & $\begin{array}{l}\text { Pertim- } \\
\text { bangan } \\
\text { Khusus }\end{array}$ & $\begin{array}{l}\text { Dengan mengelola sumber } \\
\text { intelijen dari sistem informasi } \\
\text { keamanan dan keselamatan pela- } \\
\text { yaran bekerja sama dengan KSOP } \\
\text { maka Sinergitas Potensi maritim } \\
\text { bisa menjadi nyata dan membawa } \\
\text { manfaat bersama. }\end{array}$ \\
\hline 5 & $\begin{array}{l}\text { Risiko } \\
\text { potensial }\end{array}$ & $\begin{array}{l}\text { Kemungkinan ketergantun- } \\
\text { gan KSOP pada Institusi Lanal } \\
\text { mengakibatkan beban kerja Lanal } \\
\text { bertambah. }\end{array}$ \\
\hline
\end{tabular}

informasi tersebut dalam mendukung pengumpulan data intelijen di Lanal guna operasi keamanan laut.

\section{KESIMPULAN}

Hasil Identifikasi yang dilakukan dengan SWOT mendapatkan 26 (dua puluh enam) faktor Internal dan Eksternal yang berpengaruh pada pemberdayaan komponen maritim dalam mendukung operasi keamanan laut di Selat Lombok. Dengan pendekatan juga dapat diidentifikasi prioritas faktor yang berpengaruh dan urgent pada dukungan opskamla yaitu faktor kemampuan intelijen (bobot $0,148)$, kekuatan patroli keamanan laut (patkamla) (bobot 0,107 ), faslabuh (bobot 0,058 ) serta fasilitas pendukung administrasi opskamla dan fasmako (bobot 0,052).
Rumusan strategi pemberdayaan yang dilakukan dengan pendekatan SWOT mendapatkan hasil bahwa Lanal Denpasar dan Mataram dapat bersinergi dengan komponen maritim lainnya menggunakan Strategi W-T (Defensif) guna memenuhi kebutuhan utama opskamla yaitu kemampuan intelijen, kekuatan patkamla, kebutuhan faslabuh serta kebutuhan fasilitas pendukung administrasi opskamla. Dari hasil analisis skoring dengan metode SWOT di masing-masing teritorial Lanal dapat dirumusan 6 (enam) Strategi Defensif (W-T) yang menjadi Solusi Potensial strategi pemberdayaan yang dapat dipakai dalam mendukung opskamla di Selat Lombok, dengan Strategi WT-4 sebagai strategi yang terpilih berdasarkan Low Cost High Impact.

\section{SARAN DAN REKOMENDASI}

Untuk selanjutnya dapat disarankan penerapan Solusi Potensial berupa Strategi Pemberdayaan Komponen Maritim dalam mengelola keamanan maritim di selat Lombok ataupun chokepoint lainnya, dengan pendekatan optimasi SWOT dan AHP di setiap Lanal diharapkan mendapatkan nilai optimasi dari keseluruhan faktor yang berpengaruh baik sarana, prasarana serta dukungan instansi komponen maritim lainnya di wilayah teritorial Pangkalan TNI AL untuk mendukung Opskamla.

Perumusan Strategi ini dapat direkomendasikan pada lokasi atau chokepoint Rawan lainnya di wilayah laut NKRI, untuk mendapatkan sinergitas stakeholder yang berperan dalam pengelolaan dan pemberdayaan komponen maritim dalam perspektif keamanan laut nasional dengan leading sector institusi TNI AL. 
44 | Ahmadi, A. dkk., Analisa Strategi Pemberdayaan Komponen Maritim...

\section{DAFTAR PUSTAKA}

Ahmadi, Zain, D., Soerachman \& Santoso, B., 2011. Determination of Naval Based Locations: Strategy to Maximize Performance Monitoring of Defense and Security System in The Sea Study on Maritime Security and Defense System in Indonesia). Jurnal Aplikasi Manajemen, pp.254-63.

Aji, D.R., 2015. Pembuatan Sistem Informasi Keselamatan dan Keamanan Pelayaran Berbasis Web Menggunakan Data Satelit Altimetri (Studi Kasus : Laut Jawa). Surabaya: Institut Teknologi Sepuluh Nopember.

Akimoto, K., 2001. Structural Weaknesses and Threats in the Sea Lanes. Tokyo: Institute for International Policy Studies Institute for International Policy Studies.

Ayub, A., Razzaq, A., Aslam, M.S. \& Iftekhar, H., 2013. A Conceptual Framework On Evaluating SWOT Analysis As The Mediator In Strategic Marketing Planning Through Marketing Intelligence. European Journal of Business and Social Sciences, pp.91-98.

Dinarto, D., 2016. Reformasi Tata Kelola Keamanan Maritim Indonesia di Era Presiden Joko Widodo. Yogyakarta: ASEAN Studies Center Universitas Gadjah Mada.

Dirjen Hubla, 2015. Rencana Strategis Direktorat Jenderal Perhubungan Laut Tahun 2015-2019. Jakarta: Direktorat Jenderal Perhubungan Laut.

Gorener, A., Toker, K. \& Ulucay, K., 2012. Application of Combined SWOT and AHP: A Case Study for a Manufacturing Firm. Procedia - Social and Behavioral Sciences, pp.1525 - 1534.

Gretzky, W., 2010. Strategic Planning And SWOT Analysis. In Harrison, J.P. Essentials of Strategic Planning in Healthcare. Chicago: Health Administration Press. pp.91-97.

Kadarisman, M., 2017. Kebijakan Keselamatan dan Keamanan Maritim Dalam Menunjang Sistem Transportasi Laut. Jurnal Manajemen Transportasi \& Logistik, IV(2), pp.177-92.

Kajitani, Y. et al., 2013. Economic Impacts Caused by The Failure of A Maritime Global Critical Infrastructure---A Case Study of Chemical Facility Explosion in the Straits of Malacca and Singapore. Journal of Transportation Security, pp.289-313.
Keliat, M., 2009. Keamanan Maritim dan Implikasi Kebijakannya Bagi Indonesia. Jurnal Ilmu Sosial dan Ilmu Politik, XIII(1), pp.111-29.

Keputusan Kasal Nomor 1424, 2016. Kep.Kasal Nomor KEP/1424N/2016 Tanggal $27 \mathrm{Mei}$ 2016 tentang Kebijakan Perencanaan TNI Angkatan Laut Tahun 2017. Jakarta: Markas Besar TNI Angkatn Laut.

KKP, 2015. Rencana Strategis Kementerian Kelautan dan Perikanan Tahun 2015-2019. Jakarta: Kementerian Kelautan dan Perikanan.

Megawati, A., 2014. Efektivitas Strategi Pengamanan dan Pertahanan Laut Dalam Meningkatkan Stabilitas Keamanan Daerah (Studi Kasus Pada Pangkalan TNI Angkatan Laut (Lanal) Kota Tarakan Provinsi Kalimantan Utara). Malang: Universitas Brawijaya.

Mobaraki, O., 2014. Strategic Planning and Urban Development by Using The SWOT Analysis. The Case of Urmia City. Romanian Review of Region Studies, pp.47-54.

Pemprov Bali, 2016. Rencana Strategis Pembangunan Provinsi Bali Tahun 20152019. Denpasar: Pemerintah Daerah Provinsi Bali.

Pemprov NTB, 2014. Rencana Strategis Pemerintah Daerah Propinsi Nusa Tenggara Barat Tahun 2015-2019. Mataram: Pemerintah Propinsi Nusa Tenggara Barat.

Petunjuk Umum-PUM 1.03, 2000. SKEP KASAL NO.SKEP/1394/IX/2000 ) tentang Pola pembinaan Logistik TNI Angkatan Laut. Jakarta: Mabe TNI Angkatan Laut.

Polri, 2017. Keputusan Kapolri No Kep/370/III/2017 Tanggal 31 Maret 2017 tentang Rencana Strategis Kepolisian Republik Indonesia Tahun 2015-2019. Jakarta: Mabes Polri.

Pushidrosal, 2018. Data Wilayah Negara Kesatuan Republik Indonesia. Jakarta: Pusat Hidrografi dan Oseanografi TNI Angkatan Laut.

Rodrigue, J.-P., 2004. Straits, Passages and Chokepoints A Maritime Geostrategy of Petroleum Distribution. Cahiers de Géographie du Québec , 48, pp.357-74.

Suharyo, O.S., 2017. Model Penentuan Lokasi Pangkalan Angkatan Laut Berbasis Sustainabilitas. Surabaya: Institut Teknologi Sepuluh Nopember. 